\title{
THE USE OF THE FATHER IMAGE IN IMPERIAL PROPAGANDA AND 1 CORINTHIANS 4:14-21
}

\section{Eva Maria Lassen}

Family metaphors played an important role in the formation of early Christianity. The Christian theology was centred upon filiation: God was the Father, Jesus the Son, the converts were the brothers of Christ and the true heirs of Abraham. In this article, one aspect of the use of family metaphors will be explored, namely the father-concept used metaphorically by Paul to assert his apostolic authority in the Corinthian church.

In keeping with the NT as a whole, Paul used family images (e.g. 'brother', 'sister', and 'heir') in all his letters. He employed the father-concept metaphorically in connection with Corinth in different ways, sometimes in order to describe his relationship to the congregation as a whole, sometimes to express a feeling of special concern for individuals, for instance Timothy. ${ }^{1}$ For Paul, the use of the father-image seems to have been a fundamental one for expressing his relationship to the congregations, which he had founded. Most explicitly, this appears in 1 Corinthians 4:14-21 where he attempts to bring the Corinthians back to a right perception of the Christian teachers. He used the father image as a means to convince: 'I am saying all this not to make you ashamed but to bring you, as my dearest children, to your senses. You might have thousands of guardians in Christ, but not more than one father and it was I who begot you in Christ Jesus by preaching the Good News'. He continued the argument using this father-child image: 'It is for you to decide: do I come with a stick in my hand or in a spirit of love and goodwill?'

The significance of the father image in this passage will be assessed firstly, by looking at the function of the father-image in the Roman family and secondly, the Roman use of father metaphors in the political and religious sphere in the

${ }^{1}$ E.g. 1 Cor. $4: 15,17 ; 2$ Cor. 6:13, 12:14. 
late Republic and the Principate, and finally their significance for the Christian congregation in the Roman colony of Corinth.

\section{The Roman Father}

In Republican Rome, a very strong father-figure flourished. Legally, the head of the family was pater familias, who was the oldest male in direct line. He had an overwhelming power. ${ }^{2}$ This power, patria potestas, was life-long, i.e. it lasted not merely until the children reached majority but until the father's death. A person with a living father could neither marry nor divorce without the latter's consent. Adults in potestate had no legal right to property. He or she could notwith legal validity-buy a house or sell a horse, if the father disagreed.

It is debatable to what extent the paternal power loosened during the late Republic and the early Empire. One of the questions under discussion, is whether an individualization took place in the Roman society during the late Republic, followed by a loosening of family bonds. ${ }^{3}$ Legally, however, the paternal power remained remarkably strong until late antiquity.

This very strict legal system was often softened in practice. A son could get a peculium - for instance in the form of a house, money or slaves-which he could administer as his own. The Romans also probably lived in nuclear families. ${ }^{4}$ This would mean that married adults did not live together with their father. Therefore it could be difficult for the legal head of the family actually to exercise his power. Finally, recent studies have made probable that only one in five adults over 30 years old had living fathers. ${ }^{5}$ This, of course, still

\footnotetext{
${ }^{2}$ R. Saller, \& B. Shaw, 'Tombstones and Roman Family Relations in the Principate', JRS (1984) 124. R. Saller, 'Familia, domus, and the Roman Conception of the Family' Phoenix 38 (1984) 336-55. Y. Thomas, 'Vitae Necisque potestas,' Y. Thomas, (ed.), Du chatiment dans la cité, Supplices corporels et peine de mort dans le monde antique, Ecole Francaise de Rome, (1984) $448 \mathrm{f}$.

${ }^{3}$ See e.g. J. Gaudemet, 'Le Statut de la femme dans l'Empire romain'. J. Gaudemet, Etudes de droit Romain (Milan 1979) Vol. III.

${ }^{4}$ R. Saller, \& B. Shaw, (1984) 124f; R. Saller, 'Patria potestas and the stereotype of the Roman family', Continuity and Change 1(1) (1986) 15.

${ }^{5}$ R. Saller, ibid.15.
} 
leaves the rest of the adults and a very large group of minors under patria potestas.

The pater familias was not free to act arbitrarily towards the persons in potestate. On the contrary, he was supposed to act with moderation and justice. Therefore, the Roman censor sometimes intervened if the head of the family mistreated wife or children. ${ }^{6}$ During the imperial period this public control was exercised not through the censor but through various laws. Within the family, a consilium could be gathered to advise the pater familias and thus to some extent control the exercise of his power. ${ }^{7}$ This could happen in the case of a grave offence for instance adultery, committed by a member of the family. Fatherly love was a widely held ideal, an ideal that can be traced in numerous burial inscriptions ${ }^{8}$ as well as in Latin literature. Catullus, for instance, used fatherly love as a metaphor for his tenderness towards his mistress, ${ }^{9}$ and Cicero often relied on it in his legal proceedings. ${ }^{10}$ Thus several non-legal ideals surrounding the father counter-balanced his legal power.

\section{The Roman Father as a Metaphor}

The Romans showed an affinity by using family concepts metaphorically, i.e. they used family concepts to describe phenomena and relationships outside the familial sphere. In civil war literature, for instance, these wars were described as wars between brothers; ${ }^{11}$ and in the Roman collegia, occasionally 'mothers' and 'fathers', i.e. patrons, are found. ${ }^{12}$ But the Roman state was, like the family, fundamentally hierarchical. As a consequence, we can see a predominance of the father-figure among family metaphors employed in the public sphere, including politics and religion. ${ }^{13}$

\footnotetext{
${ }^{6} \mathrm{G}$. Pieri, L'Histoire du cens jusqu'd la fin de la Republique romaine, (Paris 1968) $102 \mathrm{ff}$ and 113ff.

${ }^{7}$ W. Kunkel, 'Das Konsilium im Hausgericht', ZSS, RA LXXXIII, (1966).

${ }^{8} \mathrm{~K}$. Hopkins, Death and Renewal, (Cambridge 1983) 225.

${ }^{9}$ Catullus 72.

${ }^{10}$ Cicero, Pro Sex. Rosc. Am. 53; in Verrem II,1,12; Mur. 23.

${ }^{11} \mathrm{P}$. Jal, La guerre civile d Rome, (Paris 1963).

${ }^{12}$ CIL III, 7505; VI, 8796; 10234; IX 2687; 5450; XIV 37; 2408.

${ }^{13}$ This argument is fully developed in E.M. Lassen, Den romerske faderskikkelse
} 
In the religious sphere, the great gods were regularly called patres, e.g. Mars, Jupiter, Neptune and Saturn. ${ }^{14}$ In a few priesthoods, the father metaphors were used in connection with priests. ${ }^{15}$

In the political sphere, the senators of Rome with systematic regularity were addressed as patres or patres familias. Normally, though, the senators did not act analogously to patres familias. Rather, they served as consilium for the highest officials, primarily the consuls. The senators, then acted analogously with consilium within the family. There is, then, a similarity between the organization of the consul's power and that of the pater familias. ${ }^{16}$ Sometimes the consul was explicitly compared with a father. Cicero, for example, claimed that he had acted as a mild father when being a consul (De domo 94). ${ }^{17}$

The father-son relationship is reflected in the relationship between the proconsul (or propraetor) in the province and his quaestor, as can be seen in the writings of Cicero and Pliny the Younger. This relationship rested on mutual obligation: the proconsul should act with the same concern towards his quaestor as a father to his children, and the quaestor should show a son's pietas towards his proconsul or propraetor. ${ }^{18}$

According to Roman tradition, it sometimes happened that generals and soldiers, who had saved a group of persons or the entire people in war, were called fathers. ${ }^{19}$ This tradition started with Romulus, who gave birth to Rome. According to

('The Roman Father-Figure', Ph.D. dissertation, Odense University, Denmark 1990).

${ }^{14} \mathrm{~A}$. Wlosok, 'Vater und vorstellungen in der römischen Kultur'. In: H. Tellenbach, (ed.) Das Vaterbild im Abendland, (Germany 1978) Vol. I, 38.

${ }^{15} \mathrm{An}$ augur called the priest who had inaugurated him 'father' (e.g. Cicero, Brutus I,l) and the pater patratus was an important figure in the cult of Fetiales. K. Latte, Römische religionsgeschichte. Handbuch der Altertumswissenschaft. V, 4 (München 1960) 121f.

16J. Crook, Consilium Principis (Cambridge 1955) 5.

${ }^{17}$ See also Cicero, De Orat. III,1,3.

${ }^{18}$ Cicero, Fam. 13,10,1; In Q, Caecilium, 61; De Orat. 2 200; Red. Sen. 35; Pliny the Younger, IV,15,9; 5,6; 21,3; V,8,5; 3,1; X,26,1.

${ }^{19}$ For the evidence of this tradition, see A. Alföldi, Der Vater des Vaterlandes im römischen Denken (Darmstadt 1971) 47ff; S. Weinstock, Divus Julius (Oxford 1971) 176 ff; 200. 
tradition, the leaders Camillus, Marius and Sulla also got these titles after having saved the Roman people.

It is likely that Cicero was the first Roman to receive the title Parens Patriae by a Senatus Consultum, i.e. officially. It happened when, during his consulship, he had saved the country from the conspiracy of Catiline. ${ }^{20}$ Caesar received the title 'Father of the Fatherland' (Pater Patriae) by a Senatus Consultum. ${ }^{21}$ At the same time, the celebration of his genius began. Inside the family, the genius, i.e. the spirit, of pater familias was celebrated. Now it became the case for a public father-figure as well.

When Caesar died in $44 \mathrm{BC}$, his followers put much stress on the dead dictator being 'Father of the Fatherland'. The Roman plebs set up a column in the Forum Romanum with the inscription: 'To the Father of the Fatherland'.22 The Roman senate made the decision to call the day of Caesar's murder for parricidium. The correct translation of this term is 'The day of the Father's murder'. The Caesarian leaders focused in their propaganda on Caesar as 'Father of the Fatherland', for instance through coins. ${ }^{23}$

The Principate began with Octavian, the later Augustus. It is disputable what importance is to be put on Augustus as Pater Patriae. According to some scholars, the title played little or no role. ${ }^{24}$ Other scholars believe that it was a substantial aspect of the Augustan regime. ${ }^{25}$ The evidence in connection with Augustus as Pater Patriae, is as follows:

Augustus started his one-man rule in $31 \mathrm{BC}$, but it was not before $2 \mathrm{BC}$ that he officially received the title Pater Patriae. The sources, however, show signs that he was considered a Father of the Fatherland many years before that date. Thus Horace in the twenties BC called the young

${ }^{20}$ Cicero, Phil. II, 5,12; In Piso 3, 6; Att. 9,10, 3.

${ }^{21}$ A. Alföldi, op. cit. 66.

$2_{\text {Suetonius, Dio. Jul. } 88 .}$

${ }^{23} \mathrm{~W}$. Trillmich, 'Münzpropaganda' In: Kaiser Augustus und die verlorene Republik, (Mainz am Rhein 1988) Ab. 209.

${ }^{24}$ Th. Mommsen, RSR (Leipzig 1887) 780, A.H.M. Jones, Augustus (Great Britain 1970) 60.

${ }^{25}$ E. Salmon, The Making of Roman Italy (London 1982) 150f; A. von Premerstein, Von Werden und Wesen des Prinzipats (München 1937) 166. 
Augustus pater urbium, 'father of the Roman state' ${ }^{26}$, and gentis humanae pater et custos, 'father and protector of the human race'. In $20 \mathrm{BC}$, a coin was struck with the inscription parens conservator. ${ }^{27}$ The celebration of his genius began probably in 30 or $29 \mathrm{BC} .{ }^{28}$ The emperor's genius was incorporated in the public cult in $13 \mathrm{BC}$.

The emperor deprivatized his family, and Augustus' family became a state family. According to Suetonius, the emperor wished his family to be an example for other Romans to follow. 29 When therefore he was angry at the bachelors of Rome for preferring a life of leisure to the married state, he displayed publicly young men of the imperial family accompanied by their babies and young children. From 13 BC the imperial family also appeared on the great Ara pacis monument depicted as harmonious couples with small children. The state family frequently appeared on coins, ${ }^{30}$ and not only Augustus' but also Livia's birthday was celebrated as a public festival.

In $2 \mathrm{BC}$, the emperor officially received the title Pater Patriae from the leader of the Roman senate, Princeps Senatus. The new situation is reflected in the erection of the Forum Augustum, which in $2 \mathrm{BC}$ was created to praise Augustus. In the middle of the square, a statue of the emperor was placed bearing the inscription Pater Patriae. ${ }^{31}$

What was the impact of Augustus as a paternal leaderfigure? The emperor needed a language of loyalty. He had to cultivate the loyalty of his subjects and the subjects needed a means to show their loyal attitude publicly. By focusing on aspects of the pater patriae figure, e.g. the celebration of his genius and the formation of a state family, and finally by receiving the title, the emperor developed a common language of loyalty. The father-image of the political leader was, as we have seen, in full accordance with Roman tradition. The Romans would not accept leaders who wore signs of a king, but

${ }^{26}$ Horace, Carmen III, 24.

${ }^{27}$ W. Trillmich, op. cit., kat. 344.

${ }^{28}$ Dio Cassius, 51,19,21; Ovid, Fast. 2,637; Horace, Ode IV.

${ }^{29}$ Suetonius, Aug. 81 and $98 \mathrm{ff}$.

${ }^{30} \mathrm{~W}$. Trillmich, op. cit., Kat. 370, 371, 372.

${ }^{31}$ N. Hannestad, Roman Art and Imperial Policy, (Aarhus Univ. Press 1986) 86. 
they did not mind being lead by a 'father'.

A majority of subsequent emperors took this title. But other images of the emperor existed side by side with the father-image and regional differences played a major part. In Rome and Italy, the father aspect of Augustus played a significantly more major role than in the Eastern provinces. ${ }^{32}$ Here the emperors celebrated in the imperial cult were more often seen as a god than a father. The Pater Patriae-image had more appeal to Roman citizens and subjects with a Roman background, wherefore it was primarily in the city of Rome and in Italy, and probably in Roman coloniae, that this aspect of the imperial propaganda was the strongest.

In conclusion, the father-figure was very strong in the early Principate, applying both to the father within the family and the father metaphor used in the public sphere. Especially with Caesar and Augustus, the father-figure became an important part of the image of the political leader. This was according to Roman tradition.

\section{Corinth and the Imperial Father}

The colonists of Roman Corinth, founded by Caesar in 44 $\mathrm{BC}$, were Roman citizens, cives Romani. They and their descendants became the elite of Corinth, which accordingly was very influenced by Roman values and traditional Roman political and religious life. At the time of Paul, social prestige was identified with the Latin language and Roman culture, the Italians leaving 'an indelible stamp on the character of the city' $^{\prime 33}$

Public images were more Italian than Greek (likewise, public inscriptions were predominantly in Latin). One inscription is found referring to the genius of the colony, a Roman concept. ${ }^{34}$ A statue of Augustus, dressed as a Roman magistrate, was found in the Julian Basilica by the forum. Augustus' Italian propaganda was transferred to Corinth, this

\footnotetext{
${ }^{32}$ For the imperial cult in the East, see e.g. S. Price, Rituals and Power. The Roman Imperial Cult in Asia Minor (Cambridge 1984).

${ }^{33}$ D. Engels, Roman Corinth (Chicago 1990) 69.

${ }^{34}$ Ibid. 102.
} 
image being 'entirely suitable for a Roman colony where cult was in essence Roman rather than Greek' ${ }^{35}$

The paternal image given to the Corinthians by imperial propaganda also to a large extent was copied from Rome and Italy, Corinth being a Roman colony with leaders who were cives Romani. The Corinthians, eager to show their Romanitas, responded with inscriptions bearing the title:

To Tiberius Claudius Caesar Britannicus, son of Augustus, (and) to Tiberius Claudius Caesar Augustus Germanicus, pontifex maximus, $p$ $P$, father of the fatherland. . The citizens of the colony [by decree of the city council] and under the supervision of the magistrates [- - -and--- - - (erected this monument)]. ${ }^{36}$

This inscription, found on the agora of Corinth, is dated AD 4750 , and in it the magistrates of Corinth greeted Claudius as $p$ (ater) $p$ (atriae). It supports the contention that the official image given of the emperor in Corinth was Roman, and included the paternal image.

Given the role of coins as an important propaganda tool, the Corinthian coin struck with the superscription TI CLAVD CAESAR AVG PP provides further evidence of the promotion of the emperor as pater patriae during Paul's time in Corinth. ${ }^{37}$

As this non-literary evidence shows, in the colony of Corinth there was an idealization of the emperor, a worship of the political leader. Thus it was an official ideal to subordinate oneself to a hierarchical structure. We can therefore conclude that Roman Corinth was not dominated by old Greek democratic ideals. In contrast the father image seems to have been a powerful tool in asserting imperial authority in this important colony.

\section{The Corinthian Church and its Apostolic Father}

Given the extant evidence of the importance of the father image for secular Corinth, how does Paul use that image as he

${ }^{35} \mathrm{D}$. Gill, 'The Importance of Roman Portraiture for Headcoverings in 1 Cor. 11:2-16', TynB 41.2 (1990) 249.

${ }^{36}$ See Kent, 77 also 104 (Hadrian or Antione) 111 (c. 185) 112, 113, West 21 (Claudian ?) 7 and 42.

${ }^{37}$ See M. Amandry, Le monnayage de duovirs corinthiens, $\mathrm{BCH}$ Supp. XV (Paris, 1988) 192. 


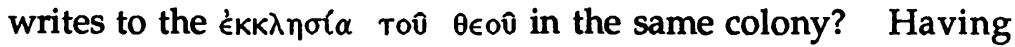
lived in this Roman colony for some eighteen months while establishing a Christian community, Acts 18:11 Paul would not have been unaware of this powerful Roman usage nor of the possibility that the congregation would interpret his discussion in 1 Corinthians 4:14-21 in the light of it. While Paul has already used a number of images to describe his task as an apostle in 1 Corinthians $1.11-4.21,38$ he uses the father image of the begetter of the Corinthian church, to describe his on-going relationship with them, 4:15.

That relationship is best understood from the preceding discussion in 4:6-13 where Paul makes telling use of the irony which always accompanied the literary device of the 'covert allusion' he refers to in 4:6.39 While the church members have been engaged in a comparison between Apollos and Paul, 4:6 Paul actually maps out his relationship with them. He does so by a comparison between the importance of the congregation as high status people, 'rich men' and 'kings', verse 8 and himself as a socially disgraced criminal coming at the end of the procession on his way to execution, verse 9. The high status terms of secular Corinth mentioned in 1:26, Paul applied by way of synonyms to the church as a whole, $4: 10$. In the same verse he used the low status secular categories from which the majority of the Christians were drawn, 1:27-8 and applied them to himself, 4:10. He further observes that they have been honoured, but he has been dishonoured; they have been well provided for, but he has had to work with his own hands; he has been mistreated and suffered much in his ministry having become in the eyes of others 'the refuse of the world' and 'the off-scouring of all things', verses 10-13. Paul invokes the father image in verse 14 which would have driven home the irony of the situation-the father experienced

\footnotetext{
${ }^{38} \mathrm{He}$ is a servant, 3:5 a planter, 3:6 a skilled master builder, 3:10, and a steward and employee of Christ, 4:1.

${ }^{39}$ For a discussion of the literary form see B. Fiori, "Covert Allusion" in 1 Corinthians' 1-4 CBQ 47 (1985) 88-90 and the deliberate removal of its covertness by Paul, see B.W. Winter, Philo and Paul among the Sophists: $A$ Hellenistic Jewish and a Christian Response, (Ph. D. Diss., Macquarie University, 1988) 208-10.
} 
inferior status and degrading treatment while his children enjoyed the very best.

However Paul explained that inflicting shame was not his purpose in writing. Rather his intention was the admonition of his dear children, for such they were because he was their founding apostle having begotten them in Christ through the gospel, verses 14-15. They are invited to imitate their father and Timothy who is Paul's beloved and faithful child in the Lord. He will come and remind them of his way in Christ which is standard Pauline mapáboors in his churches, verses 16-17.

Paul also invokes the father image as he deals with the arrogant who are puffed up against him. They are taking advantage of his inability to return by creating dissension in the church, verse 18. When he does come he might bring his rod to deal with those who oppose him. His canon of judgement will not be the rhetoric they promote but their 'power', for the latter is the essence of the kingdom, verse 19. There is a choice open to the congregation. Paul concludes his long discussion of dissension and revolt in 1 Corinthians 1:10-4:21 with the questions 'What do you wish? Shall I come to you with a rod or with love in a spirit of gentleness?' verse $21 .^{40}$

In 4:14-21 the father image was used by Paul in two ways, one in moderation, verses 14-17 and the other threatening judgement on the arrogant who have challenged his apostolic authority, verse 18-21. The choice facing the Corinthian Christians was a real one of either an 'assize' or a welcome visit by Paul.

That Paul should have so ended his lengthy discussion in 1 Cor. 1:10-4:21 with the father image of justice or moderation suggests that he is invoking an authoritative relationship over the congregation as its founding father, the impact of which is more readily appreciated when placed against the background of its imperial use in this Roman colony during the Claudian Principate.

\footnotetext{
${ }^{40}$ The possibility that the rod refers to that carried by the lectors on an assize, or even that carried by Augustus as he is portrayed as a magistrate in the Corinthian statue, cannot be discounted, although commentators look to the book of Proverbs as the origin of the allusion.
} 